
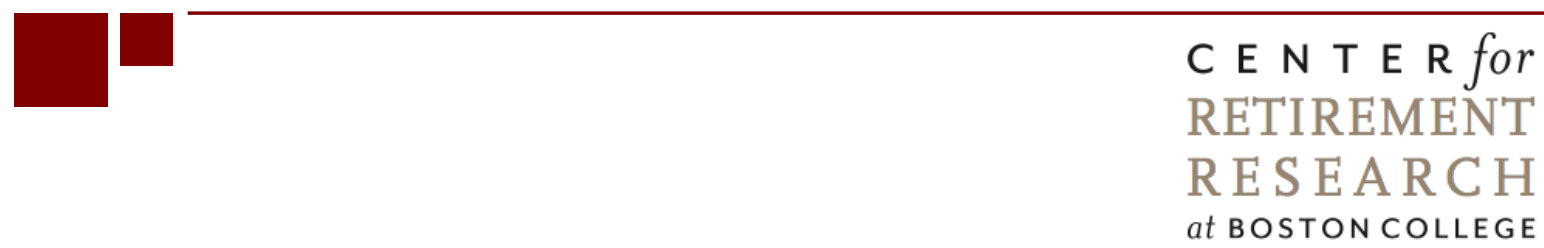

\title{
THE TRANSITION FROM DEFINED BENEFIT TO DEFINED CONTRIBUTION PENSIONS: DOES IT INFLUENCE ELDERLY POVERTY?
}

\author{
Natalia S. Orlova, Matthew S. Rutledge, and April Yanyuan Wu
}

CRR WP 2015-17

July 2015

\author{
Center for Retirement Research at Boston College \\ Hovey House \\ 140 Commonwealth Avenue \\ Chestnut Hill, MA 02467
}

Tel: 617-552-1762 Fax: 617-552-0191

http://crr.bc.edu

Natalia S. Orlova is a research associate at the Center for Retirement Research at Boston College (CRR). Matthew S. Rutledge is a research economist at the CRR. April Yanyuan Wu is a researcher at Mathematica Policy Research. The research reported herein was pursuant to a grant from the Ford Foundation. The findings and conclusions expressed are solely those of the authors and do not represent the views of the Ford Foundation, Mathematica Policy Research, or Boston College. All errors are the authors'.

(C) 2015, Natalia S. Orlova, Matthew S. Rutledge, and April Yanyuan Wu. All rights reserved. Short sections of text, not to exceed two paragraphs, may be quoted without explicit permission provided that full credit, including (C) notice, is given to the source. 


\begin{abstract}
About the Center for Retirement Research
The Center for Retirement Research at Boston College, part of a consortium that includes parallel centers at the University of Michigan and the National Bureau of Economic Research, was established in 1998 through a grant from the Social Security Administration. The Center's mission is to produce first-class research and forge a strong link between the academic community and decision-makers in the public and private sectors around an issue of critical importance to the nation's future. To achieve this mission, the Center sponsors a wide variety of research projects, transmits new findings to a broad audience, trains new scholars, and broadens access to valuable data sources.
\end{abstract}

Center for Retirement Research at Boston College

Hovey House

140 Commonwealth Ave

Chestnut Hill, MA 02467

Tel: 617-552-1762 Fax: 617-552-0191

http://crr.bc.edu

Affiliated Institutions:

The Brookings Institution

Massachusetts Institute of Technology

Syracuse University

Urban Institute 


\begin{abstract}
The transition from defined benefit (DB) to defined contribution (DC) pension plans has left workers forced to make choices that may decrease their financial resources in retirement: taking lump-sum distributions before retirement that divert funds that could support consumption in retirement, not annuitizing DC benefits, or choosing a single-life annuity over a joint-andsurvivor option so that their surviving spouses are left susceptible to income loss. This study examines pension coverage, lump-sum distributions, annuitization, and annuity life options among Health and Retirement Study households observed at ages 65-69 and 75-79 and relates these pension provisions to poverty incidence and the risk of falling into poverty at older ages. The results indicate that households with pensions that are annuitized with the joint-and-survivor life option and that do not take lump-sum distributions before age 55 are best able to avoid income and asset poverty. The results emphasize the importance of making DC plans operate more like DB plans, because the opportunities for these poor financial choices are likely only to grow given the reliance on DC plans as the sole source of employer pension income for future cohorts of retirees.
\end{abstract}




\section{Introduction}

Over the last few decades, public policy proposals and economic research have emphasized the importance of pension coverage in securing retirement well-being for lowerincome Americans. The first concern is that many lower-income households lack access to any kind of tax-deferred savings vehicle (Wu and Rutledge 2014); recent efforts, including the MyRA proposal by the Obama Administration, have focused on the low coverage rate by offering “starter” retirement savings accounts through the federal government and further encouraging employers to offer 401(k) plans.

Even for workers with access to pensions, however, the transition from defined benefit (DB) plans to defined contribution (DC) plans has left a growing number of pension holders primarily people who are still working - vulnerable to the methods in which funds are distributed. Traditionally, DB plans restricted the ability of pension holders to take lump-sum distributions, were automatically annuitized, and were legally required to default the worker into joint-and-survivor coverage to ensure that the annuity continued to pay the surviving spouse after the worker's death. These provisions ensured that retired households would avoid reducing their pile prematurely, outliving their money, or leaving their widow(er) with inadequate financial resources. DC plans, in contrast, allow easier access to lump-sum distributions (albeit with a penalty before age 591/2). They are also rarely annuitized, so retirees have to make the complicated decision of how to spend down their money over an uncertain remaining life. Even if the worker does the "right thing" and annuitizes, his spouse may be impoverished at his death if his annuity does not include a joint-and-survivor life option.

The current generation of retirees has been more fortunate, likely because the DB retirement system was set up to avoid these vulnerabilities. Greater numbers of older Americans spent most or all of their careers covered by DB pensions, with DC plans as supplementary coverage for those workers who wanted to save a little extra. Meanwhile, Social Security expanded in the late 1960s and early 1970s, covering more workers and increasing the generosity of benefits (Engelhardt and Gruber 2006). Not coincidentally, the past five decades have seen a dramatic improvement in the economic well-being of the aged (Quinn and Smeeding 1993; Smolensky, Danziger, and Gottschalk 1988). Today the old-age poverty rate is about one-third of its mid-20th century level, and Americans age 65 and older are less likely to live in poverty than younger people. But current working-age adults and their successors, who can already 
count on lower Social Security replacement rates, will also have to negotiate the minefield of lump-sum distributions, non-annuitized wealth, and single-life annuities.

This paper examines the relationship between pensions and poverty risk for older Americans, focusing on the form in which retirees receive their pension income: lump-sum distributions before age 55, annuitization, and annuity life options. The analysis uses the Health and Retirement Study (HRS) to examine the relationship between the probability of falling into poverty or near-poverty at ages 75-79 and four measures of pension coverage: (1) indicators for whether the respondent is covered in a DB or DC plan, (2) indicators for whether the respondent or his spouse have taken a lump-sum distribution from their DB or DC plan, (3) indicators for whether the respondent or his spouse reports income from an annuity, and (4) if annuitized, whether the annuity will continue to pay benefits to the surviving spouse. While most studies of elderly poverty focus solely on income poverty, this paper also includes asset poverty measures that is, whether the individual's wealth could support three months of poverty-level expenditures - to account for the wealth available to support consumption. The econometric model also includes the respondent's characteristics at age 65-69, including whether the household was already in income or asset poverty to differentiate the lifetime-poor from those who fall into poverty in old age.

The results confirm that pension coverage reduces the incidence of poverty among older households and helps them avoid falling into poverty, as expected. But one of the main contributions of this paper is the finding that the distribution provisions in DC pension plans are also critical factors in evaluating the risk of falling into poverty in old age. These provisions were never a consideration with DB plans that restricted access to lump-sum withdrawals and that were automatically annuitized with a joint-and-survivor life option. Lump-sum distributions before retirement divert funds that could benefit from compounding, decreasing the assets available to support retirement consumption; these payouts are associated with a greater risk of living in poverty. Annuitization, which provides a steady stream of income that insures households against outliving their money, is associated with a lower probability of household income falling below poverty thresholds, but single-life annuities - which stanch the flow of income at the policyholder's death - undo some of the benefits of annuitization for widow(er)s. Although DC pension holders' poverty incidence or the probability of falling into poverty is not statistically significantly greater among the current elderly than among DB holders, these cohorts 
mostly carried DC plans as supplements to DB pensions. Current cohorts more reliant on DC plans as their sole source of pension income will face the downside of DC plans - the lack of automatic annuitization with a default life option of joint-and-survivor and a greater ability to take lump-sum payouts - and will likely end up with greater poverty risk.

The consequences of these vulnerabilities are potentially severe. Poterba, Venti, and Wise (2012) report that 46 percent of individuals who have lost a spouse own less than $\$ 10,000$ in financial wealth just before their own death. Funds that are spent down too rapidly or are inaccessible to the surviving spouse leave the typical retiree relying entirely on Social Security benefits. Although Social Security lifts as many as 15 million elderly out of poverty (Van de Water, Sherman, and Ruffing 2013), it often does not lift them far out of poverty: while only 9.5 percent of individuals age 65 and older had incomes below the poverty line in 2013, another 11.5 percent fell between 100 percent and 150 percent of the poverty line (DeNavas-Walt and Proctor 2014). Ongoing increases in the Social Security Full Retirement Age (FRA) have cut benefits at any given claiming age, and reforms aiming to stave off the exhaustion of the Social Security Trust Fund could reduce benefits further. The large number of "near-poor" elderly suggests that any cuts to Social Security are likely to increase the poverty rate substantially. These cuts will increase retirees’ reliance on other sources of savings, especially pensions. Avoiding preretirement lump-sum distributions and encouraging annuitization and protection for surviving spouses will help ensure that households receive a consistent income from pension savings.

The paper is organized as follows. Section 2 summarizes the components of pension coverage and reviews the state of the literature on poverty at older ages. Section 3 describes the HRS data and the sample used in this analysis. Section 4 outlines the econometric model. Section 5 reports results, and Section 6 concludes that policy that pushes DC plans toward annuitization, the joint-and-survivor life option, and restricted lump-sum distributions will help households avoid falling into poverty in old age.

\section{Background}

Understanding the impact of pensions on elderly well-being requires more than simply knowing who receives income from a former employer in retirement. Even when DB plans dominated the pension market, these pensions did not always result in substantial income; long vesting periods or heavily back-loaded accrual schedules could result in low benefit levels for 
short-tenured employees but generous benefits for lifers at the same firm. The transition to DC plans has further complicated the picture. All else equal, DC plans are more generous than DB plans for short-tenured employees, but all else is often not equal - for example, a firm may decide to cut back its pension costs (and its generosity toward its future retirees) in the course of the transition to a DC system. Even pension participation itself differs; at firms that offer DB pensions, participation is usually automatic, but DC pensions often require eligible employees to “opt-in” to enroll (Gale, Papke, and Vanderhei 2005). ${ }^{1}$

DB and DC pensions differ in other ways besides generosity that may affect well-being. In particular, DB benefits are typically annuitized, insuring beneficiaries against outliving their savings and providing a clear mechanism for distributing pension wealth. In contrast, few DC participants annuitize their wealth, subjecting them to longevity risk and difficult decisions about how to spend down their wealth.

Assuming that retirees use their wealth during their own lives, the alternative to annuitization is to have funds distributed in one or more lump sums. Participants in 401(k) plans can withdraw funds from their accounts penalty-free at age $591 / 2$ or if a job separation occurs after age 55. An increasing number of DB plans also offer lump-sum distributions, and the plans that offer lump sums see fewer participants annuitize, indicating that lump-sum withdrawals reduce the wealth available for participants to convert into a regular income stream (Banerjee 2013). The task of determining how to spend down non-annuitized wealth can be daunting, so retirees often employ rules of thumb, such as spending 4 percent of the "pile” each year (Sun and Webb 2012). Of more concern are lump-sum withdrawals before retirement, especially around job transitions; these "leakages” have reduced retirement wealth by at least 20 percent (Munnell and Webb 2015). Lump-sum distributions before the ages at which penalties are lifted pose a greater risk to retirement well-being. But irregular withdrawals after that point also put elderly households at risk of spending their wealth too fast and outliving their accumulated savings - or too slow, if needless caution leads retirees to cut back on consumption instead of spending down the wealth they have accumulated for that purpose.

\footnotetext{
${ }^{1}$ Since passage of the Pension Protection Act in 2006, automatic enrollment in 401(k) plans has increased (Butrica and Karamcheva 2012). Hewitt Associates (2010), the Plan Sponsor Council of America (2013), and the American Benefits Institute (2013) report that 47-59 percent of employers currently offer automatic enrollment.
} 
Another concern is whether pension benefits protect the worker's spouse, whether or not benefits are annuitized. ${ }^{2}$ Upon the death of a retiree without annuitized pension wealth, his widow usually will have access to his "pile," provided that she is named as the beneficiary. But if he spends down his pile too quickly, his remaining wealth may not be enough for her to maintain her previous lifestyle. Even pension holders that annuitize, or have their wealth annuitized automatically in a DB plan, can leave spouses with inadequate financial resources if their annuity is not set up as a joint-and-survivor plan. A married retiree who selects the jointand-survivor option typically accepts lower monthly payments when both he and his spouse are alive, in return for insurance against the risk that he will die before his spouse and leave her with insufficient income. ${ }^{3}$ Whether the trade-off of lower benefits for the joint-and-survivor life option is worthwhile depends on the household's circumstances, including their financial security, but little is known about how low-income individuals make this decision; Holden and Zick (2000), and Johnson, Uccello and Goldwyn (2003) discuss the reasons retirees choose not to take out joint-and-survivor plans, but they do not focus on low-income individuals.

Given the growing importance of pension wealth at a time when Social Security replacement rates are gradually declining, the low level of pension coverage among lowerincome workers has been an area of key concern in the retirement literature, especially in recent years (Bassett, Fleming and Rodrigues 1998; Huberman, Iyenger and Jiang 2007; Munnell et al. 2009; Butrica et al. 2009; Poterba, Venti, and Wise 2010; Munnell, Fraenkel, and Hurwitz 2012). Wu and Rutledge (2014) attribute much of these low coverage rates to unstable employment in low-quality jobs, though Karamcheva and Sanzenbacher (2013) suggest that some portion of the shortfall relative to higher-income workers is due to a weaker preference for pensions: lowerincome workers do not appear to seek out jobs offering pension coverage. Each of these studies, however, focuses on only the pension coverage rate, rather than the details of that coverage. Our paper suggests that lump-sum distributions, annuitization, and annuity life options are also important factors.

Another strand of the literature focuses on how income changes over one’s retirement. One key cause of falling into poverty is widowhood (Hurd and Wise 1989; Myers et al. 1987;

\footnotetext{
${ }^{2}$ Joint-and-survivor benefits are paid only to the worker or his spouse and not to any other surviving beneficiary.

${ }^{3}$ Since 1974, the default annuity life option has been joint-and-survivor, and starting in 1984, opting for single-life annuities required the notarized signature of the spouse (Beshears, Choi, Laibson, and Madrian 2009). Making joint-and-survivor the default increased the proportion of annuities with this option by 25 percentage points (Holden and Nicholson 1998).
} 
Holden and Zick 1998; Munnell and Karamcheva 2007). The death of a spouse induces a sharp decline in household income from the loss of that person's Social Security benefit. Joint-andsurvivor provisions in private pensions ensure that total retirement income does not fall too far by paying the surviving spouse at least half of the deceased's pension income. The association between private pensions and falling into poverty after a spouse's death is less well-understood than the effect of widowhood on Social Security benefits. This paper aims to fill this gap in the literature, including a focus on the role of annuity life options in reducing the risk of falling into either income or asset poverty upon the death of the pension holder.

\section{Data and Sample}

The Health and Retirement Study (HRS) surveys U.S. residents age 51 and over every two years about their labor market activity, retirement savings, retirement expectations, health status, and other economic and family outcomes. The survey began in 1992 with a cohort of individuals born in 1931-1941, and subsequently added cohorts born earlier and later.

This study uses a sample derived from the 1992 through 2010 waves of the HRS consisting of individuals from the original HRS (1931-1941) and Children of the Depression (CODA; born in 1924-1930) birth cohorts. ${ }^{4}$ The sample consists of households in which at least one person is observed at age 65-69 and at 75-79. For coupled households in which both spouses meet the age restriction, the individual characteristics are from the financial respondent. ${ }^{5}$ Some households had two financial respondents, since the waves in which they met the age requirements were different; in this case, we kept the older financial respondent in the sample.

The sample is limited to households in which at least one member reports a positive number of total years worked. We drop any households where the coupling occurred after the age 65-69 observation, to avoid any uncertainty about whether a newly married individual is eligible for benefits from a late spouse’s pension.

\footnotetext{
${ }^{4}$ We use the first wave after the respondent's $65^{\text {th }}$ birthday, and the first after the $75^{\text {th }}$ birthday; for most people, these observations will be at ages 65 or 66 and ages 75 or 76 . The large age range after the $65^{\text {th }}$ birthday allows for inclusion of CODA respondents; the CODA cohort was first sampled in 1998, so respondents born in 1929-1930, and some born in 1928 who had not yet reached their $70^{\text {th }}$ birthday, would satisfy the requirement of being sampled in their 60s. In addition, a handful of older spouses of HRS cohort members are also sampled in both their late-60s and mid- to late-70s.

${ }^{5}$ The HRS includes information on couples who are not legally married. For the analysis of annuity life options, however, we include only the legal spouse, as the surviving member of a couple that is not legally married is not eligible for survivor benefits.
} 
Panel A of Table 1 details the sample refinement. Out of the 37,000 RAND HRS respondents, nearly 4,200 individuals are observed at both ages 65-69 and 75-79. After dropping the 600 individuals who marry after age 65 and aggregating individuals to households reporting that at least one member worked during their lives, 2,714 households remain in the sample.

\section{Methodology}

The focus of this study is on the relationship between the inherent differences in pension income distribution methods between DB and DC plans and the risk of falling into income or asset poverty at older ages. Income poverty is defined as having household income below 100 percent, 150 percent, or 200 percent of the poverty threshold. ${ }^{6}$ Asset poverty is defined as a level of total, non-housing, or financial asset wealth that would enable the household to remain above the official poverty line for three months (see Caner and Wolff, 2004). ${ }^{7}$ The explanatory variables of particular interest are pension coverage and the choice of pension payout options: lump-sum distributions before age 55, annuitization, and the annuity life option.

There are two sources of pension information at each HRS wave: the income section and the job sections. The latter include an employment section, a last job section, and a job history section. The employment section has information both on current and last wave pensions and is asked at every wave. The job history section covers pensions from pre-HRS jobs, and the last job section asks about the most recent job held before entering the survey. The pension coverage and type (DB or DC) variables use information from a household member's current job, but otherwise we ignore any pensions from a current job, since the pension payout method (annuitization and the resulting single life vs. joint-and-survivor options) is unknown until after they leave their jobs. We then identify individuals who have ever reported a pension from a past job prior to age 75-79, based on the three job sections, and record the type and payout of each pension.

A major drawback of the job sections in the HRS is that, for any given pension, respondents do not specify whether they chose a single or a joint life pension annuity. Instead,

\footnotetext{
${ }^{6}$ This paper defines "household” as the age 65-69 or 75-79 respondent and the spouse, excluding any additional members, such as children or grandchildren.

${ }^{7}$ Three types of asset levels are examined: 1) total asset wealth represents the entirety of a household's assets (home equity, savings, checking, stocks, bonds, etc.) minus any debt; 2) non-housing wealth is identical to total wealth except that it excludes home equity; and 3) financial wealth consists of checking and savings accounts, stocks, and other savings such as bond funds (for greater detail, see Rank and Hirschl 2008).
} 
we obtain data on current pension income from the income section, which is the only source of information on the type of annuity life option. This section includes information on income from up to two current pensions. Unfortunately, the type of current pension (DB or DC) is not explicitly asked, so we identify the life option associated with the source of pension income, without regard for the pension type. ${ }^{8}$

The project first relates households' choices of pension payout options to the incidence of poverty at age 75-79 (period 2) in the context of a probit model of poverty risk:

$$
\operatorname{InPov}_{i 2}=\beta W_{i 2}+\alpha_{1} \operatorname{InPov}_{i 1}+\gamma X_{i 1,2}+\varepsilon_{i 2}
$$

Multiple specifications are estimated, where each one has as its dependent variable an indicator equal to one if household income is below a certain proportion (100 percent, 150 percent, or 200 percent) of the poverty threshold, or if the household is in asset poverty (using total assets, nonhousing, and financial assets separately). The key explanatory variables are the pension parameters, $W_{i 2}$. First, we control for whether any household member reports pensions from any job, differentiating by pension type. A household member can either have a DB plan, a DC pension, or they can report a pension but fail to specify its type. Households that have both DB and DC plans are coded as having a DB plan. Only households that did not give any information on the types of its members' pension plans are coded as not knowing their pension type. For the small sample of people who say that they currently receive pension income but do not have any reported pensions, we also code them as having a pension of unknown type.

Next, we control for the chosen payout of pensions from past jobs. We include indicators for either household member ever having taken an annuity payout on a DB and on a DC plan or Individual Retirement Account (IRA). We also include an indicator for a lump-sum payout before the $55^{\text {th }}$ birthday. The age distinction reflects the fact that lump-sum distributions at or after age 55 may support consumption for early retirees, but lump-sum distributions before age 55 represent hardship withdrawals and lost opportunities to earn compound returns on assets. In the HRS, respondents are asked about the age at which they left each of their past employers.

\footnotetext{
${ }^{8}$ One way to differentiate pension types is to use responses to questions about being able to receive a different income amount or to withdraw the entire balance from the account. However, if one purchased an annuity with DC wealth, the answer to those questions would be negative and the individual would be miscoded as having DB pension income. Another potential solution is to match current pensions in payment with pensions reported at any point in the past based on start year and month, but this method yields too many inconsistencies.
} 
We assume that they took out the pension at the time the job separation occurred and control for lump-sum payments received before age 55. ${ }^{9}$ These indicators are set to one if any household member reports having ever received a lump-sum payout within the age range, regardless of the plan type.

In the final set of pension controls, which apply only to households in which the spouses die before age 75-79, we examine the annuity life options from the pension. We include four indicators that are set to one if a household member has a deceased spouse, based on whether the deceased spouse either never received pension income or had received pension income from one of the three life options - single life, joint life, or an unknown type of annuity. We identify pension income as a single life annuity if the eventually-deceased respondent says either that the income will not continue for as long as he lives or that it will not continue after he dies. We examine reported pension incomes and income types over the duration of the household member's observed marriage to that spouse; if that marriage ended in divorce prior to the respondent's death, the indicator is set to zero.

Some households are poor not because of their pension choices but because they have always had low income. To isolate the relationship between pension payout methods and poverty risk, we control for poverty status at ages 65-69. The model also includes a full set of controls, $X_{i 1,2}$ : contemporaneous socioeconomic variables; indicators for baseline health and partnership status; dummies marking a decline in health; an increase in out-of-pocket medical expenditures; and changes in partnership status due to divorce or separation between the two periods. Similar to the pension variables, all health and most of the demographic variables are measured at the household level - dollar amounts are aggregated and indicators are the maximum of individual dummies. Age, gender, race, and educational attainment covariates are the exceptions. We define age to be the age of the financial non-respondent, while gender, race, and education reflect the financial respondent.

The project then estimates the relationship between the same explanatory variables and the probability of transitioning into poverty from age 65-69 to 75-79:

$$
\left(\text { PovTrans }_{i 2} \mid \text { Pov }_{i 1}=0\right)=\delta W_{i 1}+\theta X_{i 1,2}+v_{i 2}
$$

\footnotetext{
${ }^{9}$ Lump-sum distributions from IRAs are not included because the survey does not include the age at which the IRA distribution occurs. Even if we were to use an indicator for whether any household member received a lump sum from an IRA since the most recent wave, most members of our sample entered the HRS after age 55, so very few respondents would have the opportunity to answer this question for the period before their $55^{\text {th }}$ birthday.
} 
The difference with the cross-sectional models for poverty incidence is that we do not include an indicator for poverty status at 65-69, because the only households included in these longitudinal regressions are those who were not in poverty at ages 65-69; Panel B of Table 1 reports their sample sizes.

\section{Results}

Tables 2, 3A, and 3B report summary statistics for the variables of interest in the analysis. ${ }^{10}$ Table 2 shows pension characteristics at age 75-79 for the households in our sample. The majority of households have at least one member who reported a pension from a past job. Only 18 percent of households do not report any past pension coverage. Just over half of the households with past pensions report having been covered by at least one DB plan, followed by 15 percent that do not provide any information on their past pension plans, and 10 percent that report DC but no DB plans.

The vast majority - just under 80 percent - of recipients of DB pensions report receiving annuity income. Of households that include members with a past DC pension, just 19 percent ever receive income from an annuity. ${ }^{11}$ Lump-sum payouts, on the other hand, are more common among households with DC plans: about 19 percent of households with only DC plans report a lump-sum payout before age 55, compared to 12 percent of households with only DB pensions. $^{12}$

Households in which at least one member became widowed prior to age 75 constitute about a quarter of the sample. By age 75-79, these people could potentially be receiving pension benefits from the deceased spouse if the spouse opted to get a joint life pension annuity over the course of the marriage. However, over half of the deceased spouses did not receive any pension income during the marriage at all. Households with a deceased spouse who received pension income of any type during the marriage make up 12 percent of the entire sample (including oneperson households at age 65-69 and intact couples at 75-79). Those with a deceased spouse who

\footnotetext{
${ }^{10}$ Appendix Table A1 reports the summary statistics for the remaining control variables.

${ }^{11}$ The 17 percent DC annuity rate is inflated by annuities from IRAs, which may or may not have started as DC plans. Ignoring annuities from an IRA, the proportion of households with annuitized wealth from a DC is 10 percent, which almost exactly matches the annuitization rate reported in Johnson, Burman, and Kobes (2004).

${ }^{12}$ Among households with both DB and DC pensions, nearly 30 percent have received a lump-sum distribution before age 55. Most of these distributions likely came from DC plan, but the HRS data does not allow us to distinguish between DB and DC lump-sum withdrawals. The higher rate of lump-sum receipt may reflect a greater incidence of hybrid (“cash balance”) pension plans.
} 
had a joint life pension annuity amount to only 4 percent of that full sample, indicating a low incidence in our sample of pension benefits from a deceased spouse. ${ }^{13}$

Table 3A reports households’ income poverty characteristics. Households with income below the poverty threshold in both period 1 and period 2 constitute 10 percent of our sample. In period 1, households with poverty rates under 150 percent and 200 percent of the poverty line are 22 and 34 percent, respectively, and each income poverty measure increases significantly in period 2. We also examine transitions in and out of poverty between ages 65-69 and 75-79 under each definition. Almost half of the households that are below 100 percent of the poverty line in period 1 surpass the poverty line in period 2, while only 6 percent of households not in poverty transition into it. The absolute number of households in the below-poverty group is much smaller, however, so the transition rate out of poverty overstates how often poor households improve their well-being: among all households in the sample, 4 percent move out of poverty, while 6 percent transition into it. The pattern of transitions for 150 percent of poverty line is analogous. For the 200 percent of poverty line definition, more households transition into poverty than out of it.

Table 3B shows the summary statistics for the asset poverty measures. The proportions of households in asset poverty under the total, non-housing, and financial wealth definitions in period 1 are 10 percent, 18 percent, and 34 percent respectively. The asset poverty rate, based on both total and non-housing assets, increases significantly between periods 1 and 2 . The proportion of households in financial asset poverty increases, though not by enough to make it a statistically significant change. For all definitions, transitions out of asset poverty are much more frequent than transitions into it according to the variables just among households at risk of transitioning in or out. However, when looking at transitions among all households, transitions into asset poverty are always more frequent.

Table 4 reports the results from the regressions of the income poverty measures on pension parameters, demographics, and health variables. Not surprisingly, the findings emphasize the persistence of poverty: having been in poverty at age 65-69 (by all of the poverty definitions used) is highly predictive of being in poverty at 75-79.

\footnotetext{
${ }^{13}$ Only 59 percent $(0.38 /(0.38+0.26))$ of deceased spouses with a known annuity life option had joint-and-survivor plans, which is a low percentage considering that changing from the joint-and-survivor default to single life involves a notarized signature. But among the full sample of individuals with a known annuity life option - not just the deceased - 81 percent have a joint-and-survivor annuity, and only 19 percent have a single life annuity. The full sample proportions are similar to the shares reported in Holden and Nicholson (1998).
} 
The coefficient estimates for the pension parameters largely fit the theoretical predictions, though some interesting results emerge. Having DB pension coverage is associated with a statistically significantly lower risk of having income that falls below any of the income poverty thresholds. DC coverage also seems to be associated with lower incidence of falling below the 150-percent threshold, but this coefficient in the 100-percent and 200-percent regressions is not statistically significant. The more surprising result is that the pension type does not matter - the DB and DC pension estimates are not statistically significantly distinct. Despite the fact that DC pensions are associated with less wealth accumulation, therefore, this disadvantage is not associated with higher poverty risk at older ages. The lack of a difference in poverty outcomes for DB and DC pensions could be due to the fact that DC plans for this cohort, born between 1928-1935, were still seen as a supplement to DB plans - in contrast to their counterparts in the current working-age population who generally rely solely on DC pensions.

Lump-sum distributions, in contrast, are positively correlated with having income below each poverty threshold, though this correlation is only statistically significant in the 150 percent regression. These distributions before age 55 are almost certainly not supporting retirement consumption and leakages during these years hurt most because of the lost opportunities to compound the returns on the withdrawn principal in DC plans or, if the lump-sum withdrawal closes the account, to continue to accrue DB benefits.

As anticipated, households who receive annuity payments are less likely to fall into poverty. In the regressions where the dependent variables are income below 150 or 200 percent of the poverty line, receiving annuitized income from DC pensions has a larger negative correlation with falling into poverty than receiving regular DB income, but the DB and DC annuity coefficients are not statistically significantly different from each other.

The next set of regressors compares widow(er)s at ages 75-79 to households at the same age who did not have a member die, based on whether the spouse had an annuity with single or joint-and survivor life insurance options or had never derived income from an annuity. ${ }^{14}$ As expected, widow(er)s whose deceased spouses had been collecting annuity income that would end at their death - i.e., single life annuities - are statistically significantly more likely to have income below each poverty threshold. Joint-and-survivor annuities have negative coefficients

\footnotetext{
${ }^{14}$ The four life annuity categories (single life, joint-and-survivor, annuity of unknown type, and no annuity) are exhaustive for any household where one spouse died. The omitted condition is that all of the household members at age 65-69 are still alive.
} 
(suggesting they are associated with lower poverty incidence) for the two lower poverty thresholds, but they are statistically insignificant. The results indicate that married individuals who are at least somewhat protected financially against their spouse's death are better off than households in which the surviving spouse is cut off from the deceased's income.

Most of the remaining characteristics are correlated with being below each income poverty threshold in the expected direction and are almost always statistically significant. Men, college-educated financial respondents, two-person households at 65-69, households with at least one worker at age 75-79, and households in which at least one person reports retiring before the Social Security Full Retirement Age are less likely to have income below each threshold; greater wealth also reduces the income poverty rate. Blacks, Hispanics, the less-educated, and households with at least one member in fair or poor health are more likely to have income below each threshold.

Table 5 reports the results from the panel regression, linking the probability of falling into income poverty by 75-79 among those who were not in poverty at 65-69 to pension coverage, annuitization, lump-sum withdrawals, and annuity life options. ${ }^{15}$ Having a pension is associated with a lower rate of falling into income poverty, but these coefficients are only consistently statistically significant among those households that do not report a particular pension type. Unlike with the point-in-time poverty incidence from Table 4, lump-sum distributions are not statistically significantly associated with a higher probability of falling below any income threshold. Annuity payments, on the other hand, are associated with statistically significantly lower probabilities of falling below the higher two income poverty thresholds that were analyzed. Single-life annuities are statistically significantly correlated with a higher probability of falling below each income poverty threshold, and joint-and-survivor annuities are associated with a statistically significantly lower probability of falling below the 100-percent threshold.

Table 6 reports results from regressions in which the dependent variable is falling into asset poverty, based on three different measures of assets. Repeating the pattern seen with income poverty, asset poverty at age 65-69 is positive and statistically significantly related to asset poverty at 75-79. Unlike income poverty, however, having some type of pension plan is

\footnotetext{
${ }^{15}$ The sample size is smaller at higher poverty thresholds because fewer households are above that poverty threshold at 65-69, leaving fewer people at risk of falling below that threshold. Full results are available upon request, but the coefficients for the demographic and health variables are similar in sign and significance to the estimates in Table 4 .
} 
not statistically significantly correlated with a lower asset poverty rate and the DB coefficient is not statistically significantly different than the DC coefficient. Lump-sum distributions before age 55 are not statistically significantly correlated with asset poverty incidence. Asset poverty, by its nature, is less dependent on income sources, so it is not surprising that annuity payouts are associated with lower income poverty incidence, but not lower asset poverty incidence. Using the total asset measure, single life annuities are associated with a greater incidence of asset poverty, and joint-and-survivor annuities from deceased spouses are statistically significantly correlated with lower asset poverty incidence, relative to households that did not lose a member. Surprisingly, the surviving spouse of a single life annuity recipient is less likely to fall into asset poverty based just on financial assets than intact households, but this result does not hold up for the other asset measures used. ${ }^{16}$

The point-in-time and longitudinal income poverty results from Tables 4 and 5 were quite similar, but most of the statistically significant results from the point-in-time asset poverty regressions diminish in the regressions for falling into asset poverty reported in Table 7. The only coefficients in Table 7 that are statistically significant indicate that annuities from deceased spouses where the life option is not known are associated with an increase in the risk of falling into asset poverty relative to intact households.

\section{Conclusions}

The decline in Social Security replacement rates means that pension income - primarily from 401(k)s - is going to be increasingly important in financing retirement consumption. Many current retirees can rely on DB pension income, but today's workers face the challenge of funding their retirement only with DC plans. The transition from DB to DC plans will require future retirees to negotiate their way through a minefield of challenging decisions that may reduce retirement income for themselves and their surviving spouses: lump-sum withdrawals taken before retirement, the lack of automatic annuitization and, even in households that annuitize their DC wealth, opting not to take the joint-and-survivor life option. The experience of retirees who have already made these decisions provides information on how the changes in the pension system will affect the economic well-being of future cohorts of older Americans.

\footnotetext{
${ }^{16}$ The coefficients on the demographic and health measures for the regressions in Tables 6 and 7 are similar to the income poverty estimates in Table 4, and nearly all match their theoretical prediction; these results are available upon request.
} 
The results emphasize the importance not only of pension coverage but also of the other details of the pension, including annuitization, annuity life options, and access to lump-sum distributions. These pension parameters are strongly associated with poverty risk even for current retirees, for whom the pension system is set up to avoid the pitfalls that future cohorts face. Having pension coverage is associated with lower income poverty rates in cross-section, and with a lower risk of falling into poverty as one ages, though asset poverty is less affected by pension coverage. Surprisingly, the type of pension does not appear to matter for the 1928-1935 birth cohort in this study, but most of this cohort had access to DC plans only as a supplement to DB income; workers in future cohorts that rely on non-annuitized DC plans as their sole source of retirement income are likely to be demonstrably worse off.

Though DC beneficiaries are not worse off per se, DC pension holders have easier access to lump-sum distributions before retirement, and the results indicate that households that have taken a lump-sum payout before retirement are more likely to have income that falls below each poverty threshold. Furthermore, those households with annuitized income are better able to avoid income poverty. Annuitization is almost always automatic for DB benefits, so the increased reliance on DC plans, where annuitization requires individual effort in a market that is subject to adverse selection, will likely leave some households subject to greater risk of falling into poverty. Even if the pension benefits are annuitized, the regression results in this paper indicate that deceased pension holders with single life annuities leave their surviving spouses at greater risk of falling into the lowest poverty thresholds by both income and asset measures.

These results suggest that reliance on non-annuitized DC pensions with fairly easy access to lump-sum distributions puts elderly households at risk of having insufficient income or assets to afford basic levels of consumption or, if they are not already poor at retirement, falling into poverty as the household members age or die off. The greater prevalence of DB benefits among older households who were better able to avoid these poverty-inducing practices suggests that the problem is only going to get worse. Policy interventions that encourage automatic annuitization of DC plans with a joint-and-survivor default and that discourage pre-retirement lump-sum distributions may be necessary to make sure that future generations of retirees do not fall into the traps set by poorly designed pension plans. 


\section{References}

American Benefits Institute and WorldatWork. 2013. “Trends in 401(k) Plans and Retirement Rewards.” Working Paper. Scottsdale, AZ: WorldatWork.

Banerjee, Sudipto. 2013. “Annuity and Lump-Sum Decisions in Defined Benefit Plans: The Role of Plan Rules.” Issue Brief 381. Washington, DC: Employee Benefit Research Institute.

Bassett, William. F., Michael J. Fleming, M. J., and Anthony P. Rodrigues. 1998. "How Workers Use 401(k) Plans: The Participation, Contribution, and Withdrawal Decisions.” National Tax Journal 51: 263-89.

Beshears, John, James J. Choi, David Laibson, and Brigitte C. Madrian. 2009. "The Importance of Default Options for Retirement Saving Outcomes: Evidence from the United States.” In Social Security Policy in a Changing Environment, Jeffrey R. Brown, Jeffrey A. Liebman, and David A. Wise. Chicago, IL: University of Chicago Press.

Butrica, Barbara A., Howard M. Iams, Karen E. Smith, and Eric J. Toder. 2009. “The Disappearing Defined Benefit Pension and Its Potential Impact on the Retirement Incomes of Baby Boomers.” Social Security Bulletin 69(3): 1-27.

Butrica, Barbara A. and Nadia S. Karamcheva. 2012. “Automatic Enrollment, Employee Compensation, and Retirement Security.” Working Paper 2012-25. Chestnut Hill, MA: Center for Retirement Research at Boston College.

Butrica, Barbara A. and Karen E. Smith. 2012. “The Impact of Changes in Couples’ Earnings on Married Women’s Social Security Benefits.” Social Security Bulletin 72(1).

Caner, Asena and Edward N. Wolff. 2004. "Asset Poverty in the United States, 1984-99: Evidence from the Panel Study Of Income Dynamics." Review of Income and Wealth 50(4): 493-518.

DeNavas-Walt, Carmen and Bernadette D. Proctor. 2014. Income and Poverty in the United States: 2013. Report P60-249. Washington, DC: U.S. Census Bureau.

Englehardt, Gary V. and Jonathan Gruber. 2006. "Social Security and the Evolution of Elderly Poverty.” In Public Policy and the Income Distribution, Alan Auerbach, David Card, and John Quigley, eds. New York: Russell Sage Foundation.

Gale, William G., Leslie E. Papke, and Jack Vanderhei. “The Shifting Structure of Private Pensions” In The Evolving Pension System, edited by William G. Gale, John B. Shoven, and Mark J. Warshawsky. Washington, DC: Brookings Institution Press.

Hewitt Associates. 2010. “Survey Findings: Hot Topics in Retirement 2010.” Lincolnshire, IL: Hewitt Associates LLC. 
Holden, Karen C. and Cathleen Zick. 1998. "Insuring against the Consequences of Widowhood in a Reformed Social Security System." In Framing the Social Security Debate, edited by R. Douglas Arnold, Michael J. Graetz, and Alicia H. Munnell, 165-167. Washington, DC: Brookings Institution Press and the National Academy of Social Insurance.

Holden, Karen C. and Sean Nicholson. 1998. 'Selection of a Joint-and-Survivor Pension.” Institute for Research on Poverty Discussion Paper No. 1175-98. Madison, WI: University of Wisconsin.

Holden, Karen C. and Cathleen Zick. 2000. "Distributional Changes in Income and Wealth upon Widowhood: Implications for Private Insurance and Public Policy" in Retirement Needs Framework. SOA Monograph M-RS00-1. Schaumburg, IL: Society of Actuaries.

Huberman, Gur, Shena S. Iyengar, and Wei Jiang. 2007. "Defined Contribution Pension Plans: Determinants of Participation and Contribution Rates.” Journal of Financial Services Research 31:1-32.

Hurd, Michael D. and David A. Wise. 1989. "The Wealth and Poverty of Widows: Assets Before and After the Husband's Death." In The Economics of Aging, edited by David Wise, pp. 177-199. Chicago: The University of Chicago Press.

Johnson, Richard W., Leonard E. Burman, and Deborah I. Kobes. 2004. Annuitized Wealth at Older Ages: Evidence from the Health and Retirement Study. Final Report to the Employee Benefit Security Administration. Washington, DC: U.S. Department of Labor.

Johnson, Richard W., Cori E. Uccello, and Joshua H. Goldwyn. 2003. "Single Life vs. Joint and Survivor Pension Payout Options: How Do Married Retirees Choose?” Working Paper, Washington, DC: The Urban Institute.

Karamcheva, Nadia and Geoffrey Sanzenbacher. 2014. "Bridging the Gap in Pension Participation: How Much Can Universal Tax-Deferred Pension Coverage Hope to Achieve?” Journal of Pension Economics and Finance 13(4): 439-459.

Munnell, Alicia H. 2014. "401(k)/IRA Holdings in 2013: An Update from the SCF.” Issue in Brief 14-15. Chestnut Hill, MA: Center for Retirement Research at Boston College.

Munnell, Alicia H., Rebecca Cannon Fraenkel, and Josh Hurwitz. 2012. "The Pension Coverage Problem in the Private Sector.” Issue in Brief 12-16. Chestnut Hill, MA: Center for Retirement Research at Boston College.

Munnell, Alicia H. and Nadia Karamcheva. 2007. "Why are Widows So Poor?” Issue in Brief 79. Chestnut Hill, MA: Center for Retirement Research at Boston College. 
Munnell, Alicia. H., Richard Kopcke, Francesca N. Golub-Sass and Dan Muldoon. 2009. "An Update on 401(k) Plans: Insights from the 2007 Survey of Consumer Finance.” Center for Retirement Research at Boston College Working Paper 2009-26.

Munnell, Alicia H. and Anthony Webb 2014. "The Impact of Leakages from 401(k)s and IRAs." Working Paper (forthcoming). Chestnut Hill, MA: Center for Retirement Research at Boston College.

Myers, Daniel A., Richard V. Burkhauser, and Karen C. Holden. 1987. "The Transition from Wife to Widow: The Importance of Survivor Benefits to Widows.” Journal of Risk and Insurance 54(4): 752-759.

Plan Sponsor Council of America. 2013. "56th Annual Survey of Profit Sharing and 401(k) Plans.” Chicago, IL: Plan Sponsor Council of America.

Poterba, James M., Steven F. Venti, and David A. Wise. 2010. "The Rise of 401(k) Plans, Lifetime Earnings, and Wealth at Retirement." In Research Findings in the Economics of Aging, edited by David A. Wise. Chicago, IL: University of Chicago Press.

Poterba, James M., Steven F. Venti, and David A. Wise. 2012. "Were They Prepared for Retirement? Financial Status at Advanced Ages in the HRS and AHEAD Cohorts." In Investigations in the Economics of Aging, edited by David A. Wise. Chicago, IL: University of Chicago Press.

Reno, Virginia P. and Benjamin Veghte. 2010. "Economic Status of the Elderly in the United States.” Working Paper. Washington, DC: National Association of Social Insurance.

Quinn, Joseph F. and Timothy M. Smeeding. 1993. "The Present and Future Economic WellBeing of the Aged.” In Pensions in a Changing Economy, edited by Richard V. Burkhauser and Dallas L. Salisbury, pp. 5-18. Washington, DC: NAA/EBRI-ERF Publication.

Rank, M. R., \& Hirschl, T. A. 2008. Estimating the Life Course Dynamics of Asset Poverty. Paper presented at the Panel Study of Income Dynamics Conference on Financial WellBeing Over the Life Course, November 20-21. Ann Arbor, MI.

Smolensky, Eugene, Sheldon Danziger, and Peter Gottschalk. 1988. "The Declining Significance of Age in the U.S.: Trends in Well-Being of Children and the Elderly Since 1939.” In The Vulnerable, edited by John L. Palmer, Timothy M. Smeeding, and Barbara Boyle Torrey, pp. 29-53. Washington, DC: Urban Institute Press.

Sun, Wei and Anthony Webb. 2012. "Should Households Base Asset Decumulation Strategies on Required Minimum Distribution Tables?” Working Paper 2012-10. Chestnut Hill, MA: Center for Retirement Research at Boston College. 
Van de Water, Paul N., Arloc Sherman, and Kathy Ruffing. 2013. "Social Security Keeps 22 Million Americans Out Of Poverty: A State-By-State Analysis.” Working Paper. Washington, DC: Center for Budget and Policy Priorities.

Wu, April Yanyuan and Matthew S. Rutledge. 2014. "Lower-Income Individuals Without Pensions: Who Misses Out and Why?” Working Paper 2014-2. Chestnut Hill, MA: Center for Retirement Research at Boston College. 
Table 1. Sample Selection Criteria

\begin{tabular}{lrr}
\hline Criterion & Individuals & Households \\
\hline Panel A. Poverty incidence sample & & \\
Rand HRS sample & 36,986 & \\
Observed at both 65-69 and 75-79 & 4,155 & \\
Not AHEAD & 3,636 & \\
Did not marry after 65-69 & 3,521 & \\
One observation per household & & 2,861 \\
At least one member with work experience & & 2,778 \\
Valid weights at age 75-79 & & 2,714 \\
& & \\
Panel B. Falling into poverty sample & & \\
Above 100 percent of poverty at age 65-69 & & 2,418 \\
Above 150 percent of poverty at age 65-69 & & 2,084 \\
Above 200 percent of poverty at age 65-69 & & 1,772 \\
Not in asset poverty by total assets at age 65-69 & & 2,422 \\
Not in asset poverty by non-housing assets at age 65- & & \\
69 & & 2,169 \\
Not in asset poverty by financial assets at age 65-69 & & 1,699 \\
\hline
\end{tabular}

Source: Authors' calculations from the Health and Retirement Study, 1992-2010. 
Table 2. Pension Characteristics at Age 75-79

\begin{tabular}{lc}
\hline & Sample mean \\
\hline Ever covered by DB pension & 0.581 \\
Ever covered by DC pension, but no DB & 0.098 \\
Ever covered by pension, type unknown & 0.144 \\
Never covered by pension & 0.177 \\
Annuity & \\
Ever received annuity income from DB & 0.785 \\
Ever received annuity income from DC or IRA & 0.188 \\
Lump Sum before age 55 & \\
Among HHs with a DB or a DC & 0.189 \\
Among HHs with a DB only & 0.112 \\
Among HHs with a DC only & 0.186 \\
Among HHs with a DC and a DB & 0.293 \\
Deceased spouse's annuity life option & \\
Any deceased spouse & 0.250 \\
Single life annuity & 0.026 \\
Joint-and-survivor annuity & 0.038 \\
Annuity life option not known & 0.053 \\
No annuity income & 0.133 \\
\hline Sample size & 2,688 \\
\hline
\end{tabular}

Note: All pension statistics are among people with a given pension income.

Source: Authors' calculations from the Health and Retirement Study, 1992-2010. 
Table 3A. Income Poverty Characteristics by Period

Age 65 to $69 \quad$ Age 75 to 79

$100 \%$ of poverty line

Poverty rate

0.100

0.103

Transitions into poverty (not poor at 65-69)

0.062

Transitions out of poverty (poor at 65-69)

0.484

Transitions into poverty (among all $\mathrm{HHs}$ )

0.057

Transitions out of poverty (among all $\mathrm{HHs}$ )

0.043

$150 \%$ of poverty line

Poverty rate

$0.216 * * *$

0.260

Transitions into poverty (not poor at 65-69)

0.156

Transitions out of poverty (poor at 65-69)

0.331

Transitions into poverty (among all HHs)

0.124

Transitions out of poverty (among all HHs)

0.067

$200 \%$ of poverty line

Poverty rate

$0.335 * * *$

0.414

Transitions into poverty (not poor at 65-69)

0.249

Transitions out of poverty (poor at 65-69)

0.243

Transitions into poverty (among all HHs)

0.169

Transitions out of poverty (among all HHs)

0.079

$\mathrm{N}$

2,718

2,688

Note: Asterisks denote the statistical significance of the differences between age 65-69 and age 75-79: *** $\mathrm{p}<0.01$. Source: Authors' calculations from the Health and Retirement Study, 1992-2010. 
Table 3B. Asset Poverty Characteristics by Period

Age 65 to $69 \quad$ Age 75 to 79

Total assets

Poverty rate

$0.098^{* * *} \quad 0.122$

Transitions into poverty (not poor at 65-69)

0.061

Transitions out of poverty (poor at 65-69)

0.261

Transitions into poverty (among all HHs)

0.056

Transitions out of poverty (among all HHs)

0.023

Non-housing assets

Poverty rate

$0.179 * * *$

0.214

Transitions into poverty (not poor at 65-69)

0.110

Transitions out of poverty (poor at 65-69)

0.263

Transitions into poverty (among all HHs)

0.092

Transitions out of poverty (among all HHs)

0.043

Financial assets

Poverty rate

0.336

0.351

Transitions into poverty (not poor at 65-69)

0.143

Transitions out of poverty (poor at 65-69)

0.223

Transitions into poverty (among all HHs)

0.096

Transitions out of poverty (among all HHs)

0.073

N

2,718

2,688

Note: Asterisks denote the statistical significance of the differences between age 65-69 and age 75-79: *** $\mathrm{p}<0.01$. Source: Authors' calculations from the Health and Retirement Study, 1992-2010. 
Table 4. Regression Estimates for Income Poverty at Age 75-79

\begin{tabular}{|c|c|c|c|}
\hline & \multicolumn{3}{|c|}{ Household income below poverty threshold } \\
\hline & $100 \%$ & $150 \%$ & $200 \%$ \\
\hline In poverty at age $65-69$ & $\begin{array}{l}0.120^{* * * *} \\
(0.014)\end{array}$ & $\begin{array}{l}0.179^{* * *} \\
(0.016)\end{array}$ & $\begin{array}{l}0.217^{* * *} \\
(0.017)\end{array}$ \\
\hline \multicolumn{4}{|l|}{ Pension and annuity income } \\
\hline Ever covered by DB pension & $\begin{array}{l}-0.044^{* *} \\
(0.017)\end{array}$ & $\begin{array}{l}-0.088 * * * \\
(0.023)\end{array}$ & $\begin{array}{l}-0.084^{* * * *} \\
(0.029)\end{array}$ \\
\hline Ever covered by DC pension & $\begin{array}{l}-0.027 \\
(0.020)\end{array}$ & $\begin{array}{l}-0.054^{* *} \\
(0.026)\end{array}$ & $\begin{array}{c}-0.047 \\
(0.032)\end{array}$ \\
\hline Ever covered by pension, type unknown & $\begin{array}{l}-0.032 * \\
(0.017)\end{array}$ & $\begin{array}{l}-0.136^{* * *} \\
(0.024)\end{array}$ & $\begin{array}{l}-0.126^{* * * *} \\
(0.029)\end{array}$ \\
\hline Lump sum payout before age 55 & $\begin{array}{r}0.025 \\
(0.019)\end{array}$ & $\begin{array}{c}0.041^{*} \\
(0.024)\end{array}$ & $\begin{array}{r}0.016 \\
(0.026)\end{array}$ \\
\hline Ever received annuity income from DB & $\begin{array}{r}0.014 \\
(0.017)\end{array}$ & $\begin{array}{l}-0.052^{* *} \\
(0.021)\end{array}$ & $\begin{array}{l}-0.055^{* *} \\
(0.023)\end{array}$ \\
\hline Ever received annuity income from DC or IRA & $\begin{array}{l}-0.042 \\
(0.031)\end{array}$ & $\begin{array}{l}-0.077 * * \\
(0.034)\end{array}$ & $\begin{array}{c}-0.066^{*} \\
(0.034)\end{array}$ \\
\hline \multicolumn{4}{|l|}{ Deceased spouse's annuity life option } \\
\hline Single life annuity & $\begin{array}{c}0.061 * \\
(0.032)\end{array}$ & $\begin{array}{l}0.126^{* * *} \\
(0.043)\end{array}$ & $\begin{array}{l}0.167 * * * \\
(0.052)\end{array}$ \\
\hline Joint-and-survivor annuity & $\begin{array}{l}-0.019 \\
(0.041)\end{array}$ & $\begin{array}{l}-0.068 \\
(0.050)\end{array}$ & $\begin{array}{r}0.017 \\
(0.049)\end{array}$ \\
\hline Annuity life option not known & $\begin{array}{l}-0.010 \\
(0.027)\end{array}$ & $\begin{array}{r}-0.036 \\
(0.036)\end{array}$ & $\begin{array}{l}-0.062 \\
(0.042)\end{array}$ \\
\hline No annuity income & $\begin{array}{c}0.031^{*} \\
(0.016)\end{array}$ & $\begin{array}{l}-0.002 \\
(0.023)\end{array}$ & $\begin{array}{r}0.026 \\
(0.027)\end{array}$ \\
\hline \multicolumn{4}{|l|}{ Demographics } \\
\hline Age of financial non-respondent & $\begin{array}{l}-0.002 \\
(0.001)\end{array}$ & $\begin{array}{r}0.000 \\
(0.002)\end{array}$ & $\begin{array}{r}0.001 \\
(0.002)\end{array}$ \\
\hline Male financial respondent & $\begin{array}{l}-0.028^{* *} \\
(0.012)\end{array}$ & $\begin{array}{l}-0.044^{* * *} \\
(0.016)\end{array}$ & $\begin{array}{l}-0.042 * * \\
(0.018)\end{array}$ \\
\hline Coupled household at 65-69 & $\begin{array}{l}-0.060 * * * \\
(0.014)\end{array}$ & $\begin{array}{l}-0.092^{* * *} \\
(0.020)\end{array}$ & $\begin{array}{l}-0.080^{* * *} \\
(0.023)\end{array}$ \\
\hline Divorced or separated & $\begin{array}{c}0.079 * \\
(0.041)\end{array}$ & $\begin{array}{r}0.023 \\
(0.061) \\
\end{array}$ & $\begin{array}{c}0.150^{* *} \\
(0.076)\end{array}$ \\
\hline
\end{tabular}

(continued) 
Table 4. Regression Estimates for Income Poverty at Age 75-79 (cont'd)

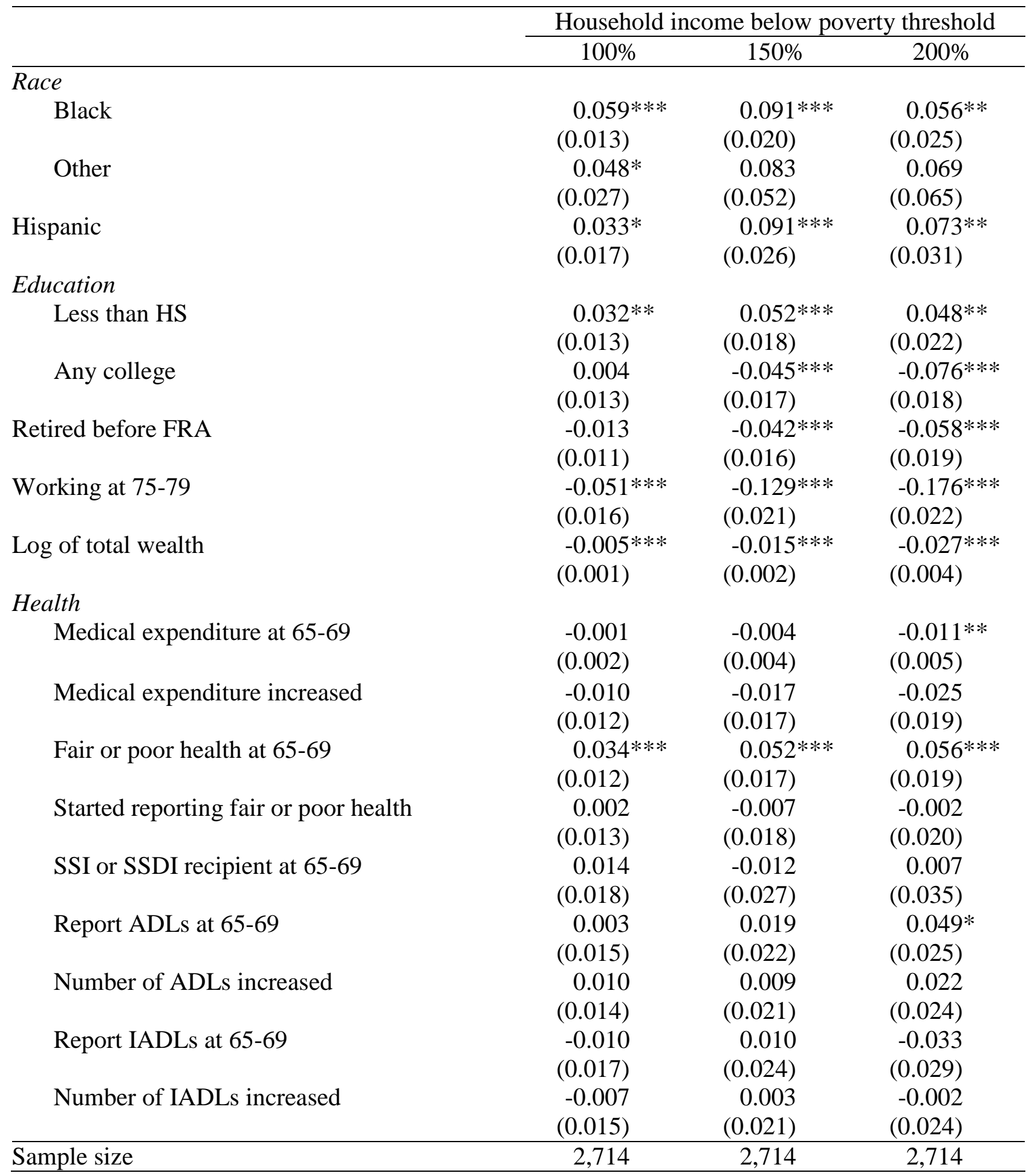

Note: ${ }^{* * *} \mathrm{p}<0.01,{ }^{* *} \mathrm{p}<0.05,{ }^{*} \mathrm{p}<0.1$.

Source: Authors' calculations from the Health and Retirement Study, 1992-2010. 
Table 5. Estimated Probability of Transitioning Into Income Poverty at Age 75-79, Among NonPoor at Age 65-69

\begin{tabular}{lccc}
\hline & \multicolumn{3}{c}{ Household income below poverty threshold } \\
\cline { 2 - 4 } & $100 \%$ & $150 \%$ & $200 \%$ \\
\hline Ever covered by DB pension & -0.019 & -0.034 & $-0.054^{*}$ \\
Ever covered by DC pension & $0.012)$ & $(0.020)$ & $(0.032)$ \\
Ever covered by pension, type unknown & -0.016 & -0.019 & -0.037 \\
& $(0.014)$ & $(0.025)$ & $(0.038)$ \\
Lump sum payout before age 55 & -0.014 & $-0.089^{* * *}$ & $-0.121^{* * *}$ \\
& $(0.013)$ & $(0.024)$ & $(0.035)$ \\
Ever received annuity income from DB & 0.007 & -0.010 & 0.002 \\
& $(0.013)$ & $(0.022)$ & $(0.027)$ \\
Ever received annuity income from DC or IRA & -0.001 & $-0.034^{* *}$ & $-0.046^{*}$ \\
& $(0.012)$ & $(0.017)$ & $(0.024)$ \\
Deceased spouse's annuity life option & -0.009 & $-0.057^{*}$ & -0.047 \\
Single life annuity & $(0.020)$ & $(0.033)$ & $(0.036)$ \\
\multicolumn{1}{c}{ Joint-and-survivor annuity } & $0.054^{* * *}$ & $0.102^{* * *}$ & $0.123^{* *}$ \\
Annuity life option not known & $0.019)$ & $(0.032)$ & $(0.052)$ \\
No annuity income & $-0.048^{*}$ & -0.023 & 0.067 \\
& $(0.025)$ & $(0.033)$ & $(0.047)$ \\
\hline Sample size & 0.023 & 0.008 & -0.038 \\
& $(0.015)$ & $(0.028)$ & $(0.048)$ \\
& $0.026^{* *}$ & -0.005 & 0.025 \\
& $(0.010)$ & $(0.018)$ & $(0.028)$ \\
\hline
\end{tabular}

Note: *** $\mathrm{p}<0.01, * * \mathrm{p}<0.05,{ }^{*} \mathrm{p}<0.1$.

Source: Authors' calculations from the Health and Retirement Study, 1992-2010. 
Table 6. Regression Estimates for Asset Poverty at Age 75-79

\begin{tabular}{lccc}
\hline & \multicolumn{2}{c}{ Assets included in asset poverty measure } \\
\cline { 2 - 4 } & \multicolumn{1}{c}{ Total } & Non-housing & Financial \\
\hline In poverty at age 65-69 & $0.213^{* * *}$ & $0.235^{* * *}$ & $0.310^{* * *}$ \\
Ever covered by DB pension & $(0.013)$ & $(0.015)$ & $(0.013)$ \\
Ever covered by DC pension & -0.006 & -0.034 & -0.015 \\
Ever covered by pension, type unknown & $(0.017)$ & $(0.023)$ & $(0.026)$ \\
& 0.021 & 0.015 & -0.002 \\
Lump sum payout before age 55 & $(0.019)$ & $(0.026)$ & $(0.029)$ \\
Ever received annuity income from DB & 0.015 & 0.012 & 0.012 \\
Ever received annuity income from DC or IRA & $(0.018)$ & $(0.024)$ & $(0.028)$ \\
& 0.012 & 0.028 & -0.023 \\
Deceased spouse's annuity life option & $(0.017)$ & $(0.021)$ & $(0.025)$ \\
Single life annuity & -0.013 & 0.013 & 0.020 \\
Joint-and-survivor annuity & $(0.015)$ & $(0.019)$ & $(0.021)$ \\
Annuity life option not known & -0.013 & $-0.060 *$ & -0.052 \\
Sample size & $(0.026)$ & $(0.034)$ & $(0.035)$ \\
No annuity income & $0.065^{* *}$ & -0.026 & $-0.137^{* *}$
\end{tabular}

Note: $* * * \mathrm{p}<0.01, * * \mathrm{p}<0.05, * \mathrm{p}<0.1$.

Source: Authors' calculations from the Health and Retirement Study, 1992-2010. 
Table 7. Estimated Probability of Transitioning Into Asset Poverty at Age 75-79, Among NonPoor at Age 65-69

\begin{tabular}{lccc}
\hline & \multicolumn{3}{c}{ Assets included in asset poverty measure } \\
\cline { 2 - 4 } & Total & Non-housing & Financial \\
\hline Ever covered by DB pension & -0.002 & -0.024 & -0.003 \\
Ever covered by DC pension & $(0.013)$ & $(0.020)$ & $(0.028)$ \\
Ever covered by pension, type unknown & 0.000 & -0.027 & 0.017 \\
Lump sum payout before age 55 & $(0.014)$ & $(0.022)$ & $(0.031)$ \\
& 0.006 & -0.018 & 0.016 \\
Ever received annuity income from DB & $(0.014)$ & $(0.022)$ & $(0.029)$ \\
& 0.005 & 0.017 & 0.024 \\
Ever received annuity income from DC or IRA & $(0.012)$ & $(0.018)$ & $(0.024)$ \\
& -0.011 & -0.002 & 0.020 \\
Deceased spouse's annuity life option & $(0.012)$ & $(0.016)$ & $(0.021)$ \\
Single life annuity & -0.034 & -0.056 & -0.043 \\
Joint-and-survivor annuity & $(0.024)$ & $(0.037)$ & $(0.033)$ \\
Annuity life option not known & & & \\
No annuity income & 0.028 & -0.053 & -0.090 \\
& $(0.021)$ & $(0.038)$ & $(0.062)$ \\
Sample size & -0.036 & 0.002 & -0.071 \\
& $(0.024)$ & $(0.031)$ & $(0.053)$ \\
& $0.034^{* *}$ & $0.042^{*}$ & $0.082 * *$ \\
& $(0.016)$ & $(0.022)$ & $(0.036)$ \\
& 0.016 & 0.022 & 0.024 \\
& $(0.012)$ & $(0.017)$ & $(0.024)$ \\
\hline
\end{tabular}

Note: $* * \mathrm{p}<0.05, * \mathrm{p}<0.1$.

Source: Authors' calculations from the Health and Retirement Study, 1992-2010. 
Table A1. Other Characteristics by Period

Age 65 to $69 \quad$ Age 75 to 79

Demographics

Age of $\mathrm{HH}$ non-representative

$64.2 * * *$

73.5

Male financial respondent

0.5

0.483

Coupled household

$0.698 * * *$

0.571

Divorced or separated

0.013

Race

White

0.879

0.893

Black

0.099

0.086

Other

0.022

0.021

Hispanic

0.058

0.050

Education

Less than HS

0.216

0.211

HS

0.370

0.377

Any college

0.414

0.412

Labor force status

Retired

$0.664 * * *$

0.844

Retired before FRA

$0.814 * * *$

0.692

Retired, disabled, not in LF

$0.756 * * *$

0.896

Working FT

$0.265 * * *$

0.072

Working PT

$0.271^{* * *}$

0.177

Unemployed

$0.022 * *$

0.014

Income and wealth

Means

Earnings

$21,500 * * * \quad 5,500$

Earnings, if positive

$44,300 * * *$

26,900

Income

$73,800 * * *$

57,200

Total wealth

$506,300 * *$

573,700

Non-housing wealth

368,400

383,800

Financial wealth

225,700

244,300

Medians

Earnings

0

0

Earnings, if positive

Income

$29,000 * * *$

13,000

Total wealth

$48,600 * * *$

35,700

Non-housing wealth

244,900

243,100

Financial wealth

$110,000 * * *$

80,800

$52,900 * * *$

39,000

(continued) 
Table A1. Other Characteristics by Period (cont'd)

\begin{tabular}{lcc}
\hline & Age 65 to 69 & Age 75 to 79 \\
\hline Health & & \\
Medical expenditure & $5,000^{* * *}$ & 5,900 \\
Medical expenditure increased & & 0.745 \\
Fair or poor health & $0.318^{* * *}$ & 0.393 \\
Started reporting fair or poor health & & 0.228 \\
SSI or SSDI recipient & $0.077^{* * *}$ & 0.040 \\
Report ADLs & $0.149^{* * *}$ & 0.239 \\
Number of ADLs increased & & 0.195 \\
Report IADLs & $0.118^{* * *}$ & 0.218 \\
Number of IADLs increased & & 0.187 \\
\hline Sample size & 2,718 & 2,688 \\
\hline
\end{tabular}

Note: Asterisks denote the statistical significance of the differences between age 65-69 and age $75-79: * * * p<0.01$, $* * \mathrm{p}<0.05$.

Source: Authors’ calculations from the Health and Retirement Study, 1992-2010. 


\section{RECENT WORKING PAPERS FROM THE CENTER FOR RETIREMENT RESEARCH AT BOSTON COLLEGE}

Will the Average Retirement Age Continue to Increase?

Matthew S. Rutledge, Christopher M. Gillis, and Anthony Webb, July 2015

The Role of Occupations in Differentiating Health Trajectories in Later Life

Michal Engelman and Heide Jackson, University of Wisconsin-Madison, July 2015

The Relationship Between Automatic Enrollment and DC Plan Contributions: Evidence from a National Survey of Older Workers

Barbara A. Butrica and Nadia S. Karamcheva, July 2015

Evidence of Increasing Differential Mortality: A Comparison of the HRS and SIPP Barry P. Bosworth and Kan Zhang, July 2015

Slowed or Sidelined? The Effect of "Normal” Cognitive Decline on Job Performance Among the Elderly

Anek Belbase, Mashfiqur R. Khan, Alicia H. Munnell, and Anthony Webb, June 2015

Does Social Security Continue to Favor Couples?

Nadia S. Karamcheva, April Yanyuan Wu, and Alicia H. Munnell, June 2015

Sources of Increasing Differential Mortality Among the Aged by Socioeconomic Status Barry P. Bosworth, Gary Burtless, and Kan Zhang, June 2015

Do Retired Americans Annuitize Too Little? Trends in the Share of Annuitized Income Barry P. Bosworth, Gary Burtless, and Mattan Alalouf, June 2015

Impact of the Financial Crisis on Long-Term Growth

Barry P. Bosworth, June 2015

Post-War Trends in Labor Income in the Social Security Earnings Records Gary Burtless and Kan Zhang, June 2015

Improving Employees' Life and Disability Insurance Benefit Decisions: Results of an Employer Survey

Anek Belbase, Norma B. Coe, and Matthew S. Rutledge, June 2015

Overcoming Barriers to Life Insurance Coverage: A Behavioral Approach

Anek Belbase, Norma B. Coe, and April Yanyuan Wu, June 2015

All working papers are available on the Center for Retirement Research website (http://crr.bc.edu) and can be requested by e-mail (crr@bc.edu) or phone (617-552-1762). 